\author{
Hill and Upland Livestock Production \\ Occasional Publication No. 10-British Society of Animal Production 1985 \\ edited by T.J. Maxwell and R. G. Gunn
}

\title{
CROSSBRED EWES FOR HILL CONDITIONS
}

\author{
J. D. BARKER, C. SMITH and N. BATEMAN \\ AFRC Animal Breeding Research Organisation, West Mains Road, Edinburgh EH9 $3 J Q$
}

\begin{abstract}
A though the value of crossbreeding in sheep is well established in Great Britain, most of the production from hill sheep is from purebred stock. Yet, in the severe environment of hill farms, the hybrid vigour of crossbred sheep could be of special value in increasing output.
\end{abstract}

ABRO's Stanhope farm in Peeblesshire provides a harsh environment of a heather hill rising to over $820 \mathrm{~m}$ and has an annual rainfall of $1000 \mathrm{~mm}$ to $2000 \mathrm{~mm}$, depending on elevation. The home-bred population of Scottish Blackface ewes, averaging about $\mathbf{8 0 \%}$ lambs born per ewe mated, were crossed with purchased rams of four other hill breeds. These were the Swaledale, North Country Cheviot, Derbyshire Gritstone and Exmoor Horn; all originating from heather hill areas. In addition, Scottish Blackface rams purchased at Lanark market were used to provide purebred controls. The resultant female progeny of each sire breed were mated, half to Stanhope Blackface rams and half to rams of the paternal breed. The reproductive performances of these half-bred ewes were compared during the first 5 years of age during the period 1977 to 1980 . A total of 687 ewes were involved, giving rise to 1481 lambings at 2, 3, 4 and 5 years of age.

When weighed at mating, Swaledale $\times$ Blackface ewes were heavier than the other breed types at all ages and Exmoor Horn $\times$ Blackface were the lightest. Purebred Blackfaces had the lowest proportion of barren ewes $(14.0 \%)$; followed by Swaledale crosses $(14.5 \%)$, which had the highest litter size (1.17).
Derbyshire Gritstone crosses had the lowest lambing percentage $(85 \%)$. Weaning weights of the lambs - at about 16 weeks - generally reflected the mating weight of the ewes, with the heaviest lambs being produced by the Swaledale crosses, and the lightest lambs by the Exmoor Horn crosses. The percentage of ewes which survived until after 5 years showed marked differences between the breed types, with $76 \%$ of the Swaledale crossbred ewes surviving to that age but only $47 \%$ of Derbyshire Gritstone crosses remaining.

The profitability of any sheep enterprise is heavily dependent upon the number of lambs sold and the weight of those lambs at sale. Numbers of lambs available for sale depend on numbers born, their survival and, particularly in the hill areas, the number of female lambs required to feed back into the flock as replacements. The lower the ewe survival rate, the higher the percentage of female lambs needed for stock breeding replacements. From every 100 Swaledale crossbred ewes mated, 74 lambs were available for sale, yielding a total of $18.1 \mathrm{~kg}$ weight of lamb (at weaning point) per ewe mated. This compares with 68 lambs from pure Blackfaces $(16.0 \mathrm{~kg}$ ); with Exmoor Horn crossbreds only yielding 53 lambs (11.1 kg weight of lamb). It is clear that the Swaledale $\times$ Blackface ewes had substantially higher output under the conditions at Stanhope than the purebred Blackfaces (which were similar to the North Country Cheviot $\times$ Blackface). Derbyshire Gritstone and Exmoor Horn crossbreds had significantly lower output and cannot be recommended under these conditions. 